\title{
Assessing Tool for the Professional Profile of the Candidate School Directors-The Greek Legislative Framework
}

\author{
Fountoulakis A. \\ Department of Electrical Engineering, \\ Technological Educational Institute of Crete, Greece \\ Kalathaki M \\ School Advisor for Science Teachers of West Crete, \\ Director of the Regional Training Center of Heraklion, Crete, Greece
}

Received: April 7, 2018 Accepted: May 28, 2018 Online published: May 31, 2018 doi:10.5296/ijhrs.v8i3.13228

URL: https://doi.org/10.5296/ijhrs.v8i3.13228

\begin{abstract}
In Greek public Education, for the selection of executives, and particularly for the Directors of Secondary Schools, teachers of public Education participate to a special process on the basis of tables that drawn up according to specified criteria defined by the respective laws. The research aimed to analyze the issue of evaluation/assessment of the professional profile of the School Directors-Candidates in Secondary Education in Greece, with the synthesis of the assessing criteria used in the last 20 years. By taking in consideration the relevant legislation, to create an Assessing Tool for the selection of Secondary schools' Directors. Through the research it was attempted to highlight how professionally structured the Greek legislation requires to be the Directors of Secondary Education regarding the scientific and pedagogical training (I), the administrative experience (II) and their personality (III). The results of the research are summarized in the 'Assessing Tool for the Candidate School Director's Professional Profile', in Secondary Education.
\end{abstract}

Keywords: valuation tool, school directors, portfolio, career options, position selection, professional profile, assessing tool

\section{Introduction}

There are many terms referring to the Head of the schools, as Principal, Headmaster, Director, 


\section{$\triangle$ Macrothink}

Leader, Manager, all together reveal the complex and demanding profession of the School Directors as public servants, officers, officials, strains, executives, managers etc. School Heads / Principals play vital role in the management and leadership of schools. There is a variety of models of school management in Europe. Some systems place a premium on 'school leaders' (or teams of leaders) who can set the pace and direction of change, facilitate open communication, stimulate creative thinking and innovation, motivate staff and students to higher levels of achievement, and exemplify the lifelong learning ethos. In other systems, the role of school leader does not exist (CEC, 2007).

The responsibilities of the leadership teams range from the simple replacement of the school head during his/her absence and administration or financial management to the coordination of certain teaching areas and the management of specific tasks. More than a dozen European countries create informal ad-hoc groups to take over specific and time-limited leadership tasks. Where local school autonomy prevails, the school head has a key role in distributing leadership responsibilities (EACEA/Eurydice, 2013). Headmaster Kashyap (2017) briefs seven major roles of headmaster, the roles in Planning, in school Organization, in Teaching, Supervision, Guidance, Maintaining Relations, General Administration. A formal day of the director, as witnessed by shadowing technique, in (Biniari L, 2016) survey, is spent on administrative tasks, guided by the tyranny of urgency and little associated with enhancing learning. Consequently, the manager's new role as facilitator and animator of change efforts is highlighted. Learning leadership is not limited to performing formal, administrative or other tasks but favors cooperative models and conducting a continuous, open dialogue on practices, difficulties, problem solving and emerging challenges. The field of the Education has become more complex and demanding in the last 20 years. The purposes and the targets are rapidly enriching and change orientations and directions. Committee Delor (1996) "Learning the Treasure Within", addressed to UNESCO, identified 4 structural axes of Education Learning to Know, Learning to Do, Learning to Live and Work Together, Learning to Exist. Lisbon European Council (LEC, 2000) in Presidency Conclusions, invited the member states to meet many targets, among them is a European framework that defines the new basic skills to be provided through lifelong learning, that was IT skills, foreign languages, technological culture, entrepreneurship and social skills (LEC, 2000). Key competences for lifelong learning, in the shape of knowledge, skills and attitudes appropriate to each context are fundamental for each individual in a knowledge-based society. The transversal nature of key competences makes them essential and provide added value for the labor market, social cohesion and active citizenship by offering flexibility and adaptability, satisfaction and motivation (EU, 2006).

The European Council in November 2006 stated that 'the motivation, skills and competences of teachers, trainers, other teaching staff and guidance and welfare services, as well as the quality of school leadership, are key factors in achieving high quality learning outcomes' and that 'the efforts of teaching staff should be supported by continuous professional development and by good cooperation with parents, student welfare services and the wider community'. The European Parliament and the Council of Europe recommended to the Member States to ensure that adults are able to develop and update key competences throughout their lives, and 
particular emphasis to be placed on target groups identified as priorities at national level, in regional and local context, such as people who need to update their skills (EP, 2006).

In Greek public Education, for the selection of executives, and particularly for the Directors of Secondary Schools, teachers of public Education participate to a special process on the basis of tables that drawn up according to specified criteria defined by the respective laws. The criteria summarized in three main categories: A. The scientific-pedagogical formatting and training, B. The administrative status, guidance and administrative experience, (C1) the personality and general formatting of the candidate, (C2) Candidate's contribution to the educational work, as evidenced by the candidate's file and interview. The group selection technique applied to a large number of candidates, which is carefully monitored by a number of observers and usually leadership skilled. This is an expensive and time-consuming selection process, which is often combined with interviews and personality tests, and its efficiency is highly dependent on the skills and abilities of the observers (Terzidis \& Tzortzakis, 2004).

In some cases, it may be necessary to define knowledge, skills and competence, also to negotiate with fragmentation of qualifications, more common in validation of non-formal and informal learning outcomes. In this way, the assessment becomes more difficult to identify whether the learner can combine all the knowledge, skills and competence in a more complex way. The validation process for non-formal and informal learning in view of achieving a qualification typically follows the following phases: identification of knowledge, skills and competences developed during personal activities, while living in a community or working, etc., documentation of these learning outcomes through the collection of evidence such as descriptions of previous working activities, etc., assessment of these learning outcomes against standards, referential or list of expected learning outcomes, award of a qualification or part of a qualification (ECVET, 2009).

Qualifications (certificates, diplomas and titles) play a significant role in modern societies as they influence the way that the individuals, education and training provide, and labor-market institutions interact. The Lisbon Strategy made the qualifications a key priority for European and national education and training policies, with the focus on transparency. Work in this area has been taken forward more tangibly by the development and implementation of European tools and principles - based on learning outcomes - that are designed to remove geographical, institutional and sectoral barriers to education and training and so promote access to, progress in, the valuing and recognition of learning. This includes the work on the European Qualifications Framework (EQF) and national qualification frameworks (NQFs), the European Credit System for VET (ECVET), quality assurance, Europass and the validation of non-formal and informal learning (CEDEFOP, 2009).

In Greece, over the last 35 years, no substantial evaluation of the educational work and teachers has been systematically applied. An exception is that of candidates for the appointment of Heads', Directors', and Advisors' positions, based on their qualifications, seniority, training, the various tasks they have undertaken during their public service, and the occasional outcome of a short interview, but it is not sufficient to assess their essential 
capabilities (Kassotakis, 2016). Given the increasing demands placed upon school leaders, and the difficulties sometimes experienced in filling leadership posts, it would also be advantageous if teachers had adequate opportunities to acquire, develop and use skills of leadership (SEC, 2007).

\section{Method}

The research aimed to analyze the issue of evaluation/assessment of the professional profile of the School Directors-Candidates in Secondary Education, with the synthesis of the assessing criteria that used in the last 20 years in Greece by the Ministry of Education. More specifically, it aimed to create, as a result, an Assessing Tool for the selection of school Directors. In Greece, relatively few researches refer to the issue. Through the research it is attempted to highlight how professionally structured the Greek legislation requires to be the modern Director of Secondary schools, i.e. their scientific and pedagogical training (I), the administrative experience (II) and personality (III) are. It is generally believed that teachers who studied in the Universities in the last thirty years, and competing for the positions of Directors in Secondary schools, have received insufficient education and training about educational administration and guidance issues. These aspects focus more on the lack of theoretical framework, methodology and practice that is required by the modern design and operating conditions of schools, and this gave the stimulus to carry out this research.

The carried out qualitative research was a content analysis, a discourse analysis, in Laws and Presidential Decrees (PDs), that referred to the selection process for the Directors in Greek Gymnasiums and Lyceums (Cohen, 1994; Bird M, 1999; Iosifidis, 2003). The content analysis helped in identifying the existence of specific words and phrases, meanings, in the studied texts and to organize the terms qualitatively and quantitatively as a result-deduction technique, distinguishing objectively and systematically identified features through the meaningful messages that emit (Bell, 1997). As unit of analysis, was taken the sentence / phrase to group and codify similar views so that they can be entered in the categories, thus responding to the research sub-queries of the research objects. For the needs of the research analyzed the following Laws and Presidential Decrees (NT, 2015): Law 4327 / 14-05-2015 "Urgent Measures for Primary, Secondary and Tertiary Education and Other Provisions", Law 3848 / 19-05-2010 "Upgrading the role of the teacher - establishing rules for evaluation and meritocracy in education and other provisions", Law 3467 / 21-06-2006 "Selection of primary and secondary education staff, regulation of administration and education issues and other provisions", Law 4186/2013, Art 39 "Pre-service in Gym Education", Law 2043 / 19-5-1992 "Supervision and Administration of Primary and Secondary Education and Other Provisions" Law 1824 / 30-12-1988 "Regulation of Educational Issues and Other Provisions", Law 1566 / 30-9-1985 "Structure and Operation of Primary and Secondary Education and Other Provisions", Law 1304 / 7-12-1982 "On Scientific-Pedagogical Guidance and Management in General and Secondary Technical-Vocational Education and Other Provisions". The Presidential Decrees (PDs) based on the laws 1566 / 30-9-1985, 1304 / 7-12-1982 and 2043 / 19-5-1992, that were analyzed, are the following: PD 25/7-2-2002 "Redefining Qualifications and Selection Criteria for Primary and Secondary Education Executives and Modifying the Selection Process" and PD 398/1995 "Determination of 
Qualifications, Criteria and Procedure of Selection of Primary and Secondary Education Executives".

In order to answer the basic query of the research, that was the valuation of the professional profile of the Candidate School Director's Professional profile, in Secondary Education, it was analyzed in three general research sub-queries, to which eight specific evaluation objects were assigned (Table 1.).

Table 1. Assessing Objects of the Candidate School Director's Professional Profile

\begin{tabular}{l|l|l}
\hline \multirow{2}{*}{ Research query } & \multicolumn{1}{|c|}{$\begin{array}{c}\text { Research } \\
\text { sub-queries/general } \\
\text { evaluation objects }\end{array}$} & \multicolumn{1}{c}{$\begin{array}{c}\text { Specific evaluation } \\
\text { objects }\end{array}$} \\
\hline & $\begin{array}{l}\text { I. Scientific and } \\
\text { pedagogical education }\end{array}$ & $\begin{array}{l}\text { Ia. Education-study titles } \\
\text { Ib. Training certifications }\end{array}$ \\
\cline { 2 - 3 } $\begin{array}{l}\text { Assessment of candidate } \\
\text { school director's } \\
\text { professional profile }\end{array}$ & II. Educational biography & $\begin{array}{l}\text { IIa. Professional } \\
\text { Experience } \\
\text { IIb. Participation in } \\
\text { research/educational } \\
\text { programs } \\
\text { IIc. Ergographic } \\
\text { IId. Educational/training } \\
\text { work }\end{array}$ \\
\cline { 2 - 3 } & III. Personality & $\begin{array}{l}\text { IIIa. Competencies } \\
\text { IIIb. Skills }\end{array}$ \\
\hline
\end{tabular}

The Assessment Criteria for the Candidate's Professional Profile are specified in the Special Objective of Assessment in Tables 2, 3, and 4. The results of the research are summarized in the 'Assessing Tool for the Candidate School Director's Professional Profile', based on the Greek legislative, answering the research sub-queries of the research objects: I. Scientific-Pedagogical Formation and Training, II. Professional status and Guidance-Administrative experience, III. Contribution to the Educational Work-Personality-General Formation of the candidate.

\section{Results and Discussion}

The economic, political and social change in Europe has caused many problems in education systems and more specific in school leadership, so attention should be focused on a small number of particularly important points related to school governance, the recruitment and careers of head-teachers, their appraisal and their training. The head-teachers must have the means to develop the schools, they must be able to concentrate on the essentials to ensure their students' success (UNESCO, 2006). In Greece, according to teacher evaluation criteria that have been proposed during the last decades, teachers must have skills that require good initial education and systematic training, such are the excellent scientific training on their subject, the knowledge and skills of the teachers in the design, organization and conduct of teaching, the proper use of teaching tools, the ability of evaluate students, the communication skills and many others. Candidates for leadership positions should be identified as early as possible among interested teachers or those with appropriate aptitudes. That would enable a transitional arrangement to be made involving limited responsibilities in the field of teaching and more in leadership (UNESCO, 2006). The Greek system of initial teacher education, 
which could help teachers acquire the appropriate qualifications, is inadequate to response the recorded training needs of teachers, for example the lack of psycho-pedagogical training of secondary teachers (Kassotakis, 2016).

For the positions of school Directors of Secondary Schools, state teachers are invited to apply on the basis of tables that drawn up according to the Ministerial announcements. Teachers of the relevant Education Level with at least ten (10) years on duty as teachers, with teaching duties for at least eight (8) years in Primary or Secondary Education, are usually eligible (Law4327/2015). The corresponding preconditions of the previous laws were $8 / 5$ in the Law3848/2010 and 12/8, In the Law3467/2006. The categories of criteria in the Laws of the recent three circles of selection, were in generally the same but rated differently, also had expressive differences in the terms of 'evaluation' and 'valuation'.

The Greek Laws referred on selection criteria which correspond to the research objects of this study. The Evaluation Criteria for the Research Objects are listed in the General and Special Research Objectives in Tables 2, 3, and 4. According to the Law 3848/2010, the selection criteria (Research Objects) for education staff of Secondary schools in Greece are: (a) Knowledge of the subject-matter of the work to be carried out by: (aa) scientific and pedagogical formation and training, as evidenced by the details of the candidate's file and the supporting evidence and the administrative status, guidance and administrative experience, as evidenced by the candidate's file. (b) The personality and general formation of the candidate, as assessed during the oral interview before the competent selection board. c) The candidate's contribution to the educational work from the positions she/he has served on the basis of the relevant evaluation reports. d) Assessment of the educational work, as evidenced by the candidate's evaluation reports was done by the Law 3467/2006.

The Scoring of Selection Criteria for the Directors of the Greek Model Experimental Schools in 2012 based on the circular 361.22/116672/ $/ \Delta 1 / 15-10-2012$. The Greek Government's Leaflet on the 'Definition of criteria for the evaluation of directors and teachers in the Model Experimental Schools' has become in the fields of Training and scientific work (up to 31/100 points), Teaching experience (up to 44/100), and Interview (up to 25/100 points).

\subsection{Scientific - Pedagogical Formatting and Training}

Career management skills can be trained by teachers in schools, in cooperation with school counsellors, combining career guidance with other tasks (learning to learn, social counselling) or with external career guidance counsellors, such as special youth guidance centers or public employment services. In times of digitalization support is increasingly offered through blended methodology in guidance and service, i.e. as much as possible online information, self-help tools (e.g. personality, occupational tests) in combination with interactive e-services (chat, Skype), group sessions and individual counselling depending on the individual needs (Kraatz, 2017). Work in group allows for additional learning effects as others can assess one's strengths and communicative performance. Content on school management should be included in teacher training to assist relations with head-teachers and to alert teachers from the onset of their careers to leadership roles. That will enable teachers who might have the taste or aptitude to be involved in it quite early, or potential head-teachers to be identified. 
Account should be taken of the complexity of the head-teacher's profession by providing flexible personalized training before entry into the profession or in the beginning of their career (UNESCO, 2006).

The criteria that answer to the research sub-query/object for the Scientific-Pedagogical Education and Training of the Candidate Secondary School Director are contained in the Table 2. As shown by the necessary documentation and evidence of the portfolio of Candidates, they measured with 9 points (Law4327/2015), 24 points (Law3848/2010), 14 points (Law3467/2006) maximum.

Table 2. Assessing Tool for the Candidate School Director's Scientific and Pedagogical Training, in Secondary Education

\begin{tabular}{|c|c|c|}
\hline & A. Education-Study Titles & $\begin{array}{l}\text { 1. Basic degree } \\
\text { 2. Additional degrees } \\
\text { 3. Postgraduate Diploma } \\
\text { 4. Doctoral Diploma }\end{array}$ \\
\hline $\begin{array}{l}\text { I. Scientific and } \\
\text { Pedagogical Education \& } \\
\text { T } \\
\text { raining (studies, titles, } \\
\text { certifications) }\end{array}$ & B. Training Certifications & $\begin{array}{l}\text { 1. Teaching and Pedagogical } \\
\text { Adequacy } \\
\text { ASPAITE), } \\
\text { Bachelor of Pedagogical } \\
\text { Academy, } \\
\text { Diploma of Eduraduate } \\
\text { Studies) } \\
\text { 2. Leadership adequacy } \\
\text { (EKDDA) } \\
\text { 3. ICT certification a, b level } \\
\text { 4. Foreign languages } \\
\text { 5. Educational Programs/ } \\
\text { Seminars } \\
\text { 6. Conferences, Congresses } \\
\text { 7. Other }\end{array}$ \\
\hline
\end{tabular}

The points are allocated as follows:

a) Doctoral degree (Ph.D.): 4 points (Law4327/2015/6(Law3848/2010)/ 6 points for the first and 0 (Law4327/2015)/6,5 points totally for more than one doctoral degree (Law3467/2006).

b) Master's degree (MSc, Med): 2.5 points (Law4327/2015)/4(Law3848/2010)/2,5 points (Law3467/2006). If there are more than one, 0 (Law 4327/2015)/6,5 points (Law3467/2006) are attributed the max. If the candidate holds a $\mathrm{PhD}$ and a $\mathrm{MSc} / \mathrm{Med}$, he receives a maximum of 4 points (Law4327/2015)/5,5 points (Law 3467/2006) (Law4327/2015). Doctoral or postgraduate diplomas which were necessary for the appointment are not awarded. If the candidate has a PhD and a MSc/Med diploma in the same subject, only the Ph.D. is awarded.

c) Second degree in a University or Technological Educational Institute (TEI): 2 points (Law 4327/2015)/3 points (3848/2010)/2 points (Law3467/2006)

d) Degree in Pedagogical Academy or Kindergarten School: 0.5 point (Law 4327/2015)/1 point (Law3848/2010)

e) Certificate of annual training in Schools of Training (SELME, SELDE, ASPAITE, 
SELETE), 0.5 point (Law 4327/2015)/1 point (Law3848/2010)/1 point (Law3467/2006). More than one certificates, they are not aggregated.

f) Qualified training in ICT level 1: 0.5 point (Law4327/2015), 2 points (Law3848/2010), 0.25 point (Law3467/2006). Advanced training in ICT level 2: 0 point (Law4327/2015), 3 points $(3848 / 2010)$. If there are training qualifications at both levels, only the upper one is awarded.

(g) Certified knowledge of foreign language at B2 level: 0.5 point (Law4327/2015)/1,5 points (Law3848/2010)/0.5 point (Law3467/2006).

h) Certified knowledge of a foreign language with a level above the B2: 1 point (Law4327/2015)/2,5 points (Law3848/2010)/1 point (Law3467/2006). If the candidate has various levels of knowledge of the same foreign language, only the certified knowledge at the upper level is being awarded. Certified knowledge of a second foreign language is calculated by half of the grading of the first foreign language. In any case, irrespective of the number of foreign languages and the applicant's level of linguistic competence, the rating units are counted as a maximum of 2 (Law3467/2006).

i) Semester training is valuating with 0.5 point (Law3467/2006) and three-month training with 0.25 point (Law3467/2006).

The Greek Pedagogical Institute materialized a Pan-Hellenic survey on the profile and training needs of the Greek teachers in Secondary and Primary Education in 2010 (MPE, 2010). In the results of this survey, comparing the levels of education with the type of university studies, the teachers of Secondary Education had the highest rates both in the possession of a 'Master's Degree' and 'Doctorate Diploma'. A satisfactory percentage $(30.07 \%)$ was reflected in the total of teachers with a certified Foreign Language (Primary $23,5 \%-26,4 \%$-Secondary $30.9 \%-34.9 \%$ ). With regard to the level they classify themselves based on their knowledge of New Technologies, teachers appear to be divided between the variables "Good", "Very good" and "Excellent" with 52\% and the variables "Moderate", "Beginner" and "Do not know at all" with $47 \%$.

Professional development for school leaders is vital because they are responsible for creating an environment in which students and teachers benefit from schools as learning communities. However, only few countries have obligatory in-service training for school leaders. The continuing professional development of all teachers and trainers and school leaders needs to equip them with the pedagogical and other competences necessary to take on the new roles implicit in this approach. It is also vital to make the teaching profession more attractive and better supported (JEU, 2010). A European diploma for basic IT skills, with decentralized certification procedures, should be established in order to promote digital literacy throughout the Union, as recommended the Lisbon European Council (LEC, 2000).

Basic communication skills in foreign languages consist of the ability to understand oral messages, initiate, process and complete conversations, and analyze, understand and produce texts appropriate to their needs. Individuals should also be able to use appropriate devices and learn languages, albeit informally, in the context of lifelong learning (EP, 2006) The joint 


\section{Macrothink}

International Journal of Human Resource Studies

ISSN 2162-3058

2018, Vol. 8, No. 3

progress report by the Council and the Commission on the implementation of the Education and Training 2010 work program requires more attention to be paid to communication in foreign languages and to the full range of "Transversal Basic Skills" which are becoming increasingly important in view of the evolving labor market and the needs of society (ECC, 2010). In Greek foreign language education, there is a lack of a curriculum on language levels, a lack of appropriate language teacher training, a lack of ICT laboratories in the Primary School, where the use of new technologies is not mandatory (NSSD, 2010).

School Directors who had taken part in the research of the Greek Pedagogical Institute in 2010, suggested the topics of Modern Learning Approaches, Exploiting New Technologies, and Didactic Methodology in Cognitive Objects, School Classroom Management and Developing Creative Relationships with students and parents as very important for their training. The topics of Intercultural Education, Counseling and School Vocational Guidance and Self-Assessment of the School Unit were referred with less importance. The main thematic section that proposed was the training in Administration and Educational Policy (MPE, 2010).

\subsection{The Professional Status, Guidelines and Administrative Experience}

Almost everywhere in Europe, teaching experience is the basic condition for appointment of School Directors, with the amount of required experience to be varied among the most countries. Among the requirements for becoming a school head, a minimum period of professional teaching experience is common. It ranges from three to seventeen years. In most countries, training for headship is required taking place before the appointment with varying duration. Common modules include management, team building, communication and leadership skills, school development, school law and organization. Some countries clearly define a practical component besides the more theoretical content (EACEA/Eurydice, 2013).

The criteria that answer to the research sub-query/object for the Educational Biography (administrative status, guidance and experience) of the Greek Candidate School Directors' in Secondary Education are contained in the (Table 3) 


\section{Macrothink}

International Journal of Human Resource Studies

ISSN 2162-3058

2018, Vol. 8, No. 3

Table 3. Assessing Tool for the Candidate School Director's Educational Biography, in Secondary Education

\begin{tabular}{|c|c|c|}
\hline \multirow{4}{*}{$\begin{array}{l}\text { II. Educational } \\
\text { Biography } \\
\text { (administrative } \\
\text { status, guidance and } \\
\text { experience) }\end{array}$} & A. Professional status & $\begin{array}{l}\text { 1. Teaching Experience } \\
\text { 2. Serve in Head positions } \\
\text { 3. Participation in Boards, } \\
\text { Committees } \\
\text { 4.Other }\end{array}$ \\
\hline & $\begin{array}{l}\text { B. Participation } \\
\text { Research/Educational } \\
\text { Programs }\end{array}$ & $\begin{array}{l}\text { 1. Scientific Program of } \\
\text { Specialty } \\
\text { 2. Educational Program } \\
\text { 3. Organization, } \\
\text { Coordination and } \\
\text { Implementation } \\
\text { Educational Actions } \\
\text { 4. Other }\end{array}$ \\
\hline & C. Ergographic & $\begin{array}{l}\text { 1. Books } \\
\text { 2. Collective Volumes, } \\
\text { Conference Proceedings, } \\
\text { etc. } \\
\text { 4. Articles in Scientific } \\
\text { Journals and Congresses } \\
\text { 5. Multimedia Educational } \\
\text { Applications } \\
\text { 6. Scientific Dissertations } \\
\text { 7. Articles in Newspapers, } \\
\text { Magazines } \\
\text { 8. Speeches, Exhibitions } \\
\text { 9. Other }\end{array}$ \\
\hline & $\begin{array}{l}\text { Dork } \\
\text { Educational/Training }\end{array}$ & $\begin{array}{l}\text { 1. Courses Teachings } \\
\text { 2. Lectures in Seminars, } \\
\text { Educational Programs, etc. } \\
\text { 3. Other }\end{array}$ \\
\hline
\end{tabular}

The benchmark criterion of the guiding and administrative experience is valued at a maximum of 14 points (Law 4327/2015)/12 points (Law 3848/2010), which are allocated as following:

B1. Professional status. Professional status rated with 11 points (Law 4327/2015)/8 points (Law 3848/2010) maximum. These points are calculated on the basis of the 'teaching experience' valued at 1 unit per year, over and above the time required for participation in the process of selecting Directors of Education and School Directors (Law 4327/2015). With the Law 3848/2010, these points are calculated upon the basis of the 'educational experience' valued by 0.50 point for each year, beyond the time required for participation in the selection process. The differentiated reading of the educational and teaching experience, among the others, sparked many debates, and raised many issues in the selection of 2015.

With the Law 3467/2006, the educational - teaching experience valuated max. 22 points of merit. These units were calculated on the basis of: (i) the total educational experience valued at 2 points for each year over those requested for participation in the selection process and up to a maximum of 8 credits, (ii) teaching experience valued at 2 points for each year in excess of the required for participation in the selection process and up to a maximum of 12 points.

B2. Administrative and Guidance experience. Administrative and Guidance experience rated with maximum 3 points for School Directors (Law 4327/2015)/6 points (Law 
3848/2010). Particularly: (i) Service with specialization in case study and ii) Participation in central, senior and regional service councils or personnel selection councils 0.25 points per year, and in 2015 as an elected member up to a maximum of 1 unit (Law 4327/2015). Participation in central, senior regional and regional boards of personnel councils or executives' selection councils in public and general government bodies, prefect or vice-mayor, mayor or deputy mayor 0,25 point for each year of participation and up to 3 points highest limit (Law 3848/2010, 4327/2015)/ 0.5 point per year and up to 1 point (Law 3467/2006). Parallel participation in more councils at the same time is not aggregated cumulatively.

In a research based on the governmental "myschool base" data about the demographics of School Directors of Secondary Education in Greece by (Kordis, 2015) elected member of the Central Service Personnel Council for Secondary Education in Greece (KYSDE), in 2015 selection in Greece, the average year of Directors' Service was 21 years, ranging from 2 to 35 years, with approximately a uniform distribution from 10 to 32 years of Service. The average age was 50 years, ranging from 29 to 65 years old, with the greatest accumulation from 48 to 58 years of age.

A successful principal candidate in Rocketship schools should have the following skills and experience, at least 5+ years of experience as a Principal, demonstrated significant student achievement results as a school leader and in-depth experience in school leadership and leading Principals. She/he should have experience inside or working with an urban, public school district, five or more years as a manager, including a demonstrable track record of assembling effective teams, strategic planning, communicating a vision and setting priorities, managing team execution, delegating, mentoring others and developing emerging leaders (Rocketship, 2017).

\subsection{Contribution to Educational Work-Personality-Character Formation}

Transformational leadership provides school leadership with a normative approach that makes progress particularly in the process by which leaders can influence school achievements, and not only regarding results. The literary review of leadership, leadership styles, and a leader's value systems with emphasis on school principals by (Jamal, 2014) indicates clear signs of the contribution of transformational leadership on the improvement in functioning of school management, particularly on teaching processes as reflected in the students' learning. The competence-based approach involves the skills and attitudes to apply knowledge appropriately, and the development of positive attitudes towards further learning, critical thinking and creativity. This represents a real challenge for the educational or training organization and depends crucially on the capacities of its teachers and school leaders/Directors. It also requires schools to be more explicitly responsible in preparing students for further learning as a core part of their mission (JEU, 2010).

The criteria that answer to the research sub-query/object for the Personality \& Contribution to the Educational Work of the Candidate Secondary School Director are contained in the Table 4. They rated, in totally, with 12 points in maximum, in the selection of 2015 (Law 4327/2015). In all selections, the interview was the main criterion for assessing the status of candidate's character, except in 2015 , when this criterion was valued by the secret vote of the 
school teachers. Law 3848/2010 foresaw making the interview more structured, on a subject from prior known issues contained in a depository of case studies, in order to avoid arbitrariness.

Table 4. Assessing Tool for the Candidate School Director's Personality \& Character Formation, in Secondary Education

\begin{tabular}{|c|c|c|}
\hline \multirow{2}{*}{$\begin{array}{l}\text { III. Personality } \\
\text { (personality tribution to and } \\
\text { contribution } \\
\text { educational work) }\end{array}$} & A. Competencies & $\begin{array}{l}\text { 1. Perceptual capacity } \\
\text { 2. Communication } \\
\text { 3. Cooperation } \\
\text { 4. Development of initiatives } \\
\text { 5. Troubleshooting } \\
\text { 6. Creating a pedagogical } \\
\text { climate }\end{array}$ \\
\hline & B. Skills & $\begin{array}{l}\text { 1. Physical presence } \\
\text { 2. Achievements, rewards } \\
\text { 3. Relationships } \\
\text { 4. Attitudes } \\
\text { 5. Adaptability } \\
\text { 6. Artistic work }\end{array}$ \\
\hline
\end{tabular}

C1. Contribution to the educational work. The candidate's contribution to the educational work is derived from the positions that she/he has served. It rated with 12 points based on the evaluation reports that the candidate has (Law 3848/2010) and with 44 points with the Law 3467/2006. Since, no evaluation has been applied for teachers in Greece, this criterion was inactive. The individual teacher evaluations, which were to be made by the School Directors and the School Advisors under the Laws 2986/2002 and 3848/2010, concerned primarily teachers who would be permanently staffed, or permanent teachers who would like to be considered as teaching staff, school advisors, those who would like to be evaluated, and any other case they felt necessary (Kassotakis, 2016).

(Hardman, 2011) showed in a research the strong correlation between the transformational factor of idealized Influence Behaviors of the Principal's Leadership Style and the Effects on Student Achievement. As stated in the same study, idealized influence behaviors include charismatic leadership vision and outgoing behaviors that inspire others to follow. These transformational leaders create a school culture with a permeating vision that consistently inspires teachers and other stakeholders throughout the school. This inspiration is said to lead to a more productive and positive school culture.

In most Laws for the school Director's choice, it is stated that the next law's enforcement will also consider the teachers' and Directors' evaluation report, which has never been done in Greece, since each new round of selection was made with a new law and no evaluation has been applied to the teachers. This avoided the need to evaluate the teaching work and the candidate's personality assessment and was replaced by Interview in front of Council board, except the selection of 2015 when used secret voting by the teachers of the school where was each one candidate (Kassotakis, 2016).

C2. Personality \& General Character Formation. Personality and general character formation rated maximum 15 points with the Law 3848/2010. This criterion was assessed by a personal interview of the candidates in front of the selection board under Article 16 (3848/10), which assessed the personality, professional development and skills of the 
candidate.

According the Law 3848/2010, to assess this criterion, a type of personal interview was used with model templates, including the assessed elements such as physical presence, achievements, interpersonal skills, attitudes, adaptability with the relative weighting. The Selection Board could, by a unanimous and fully reasoned decision, to exclude from the further procedure a candidate who, during the interview, was found not to be suitable for his/her duties (Law 3848/2010). The interview in front of a selection board ensured the transparency. In order to classify the interview, the Selection Board could take into account the information that the candidate mentioned in his curriculum vitae, which was evidenced by documents (copies, attestations) and which had not been graded in another way, such as other studies, training and retraining, conferences, seminars and educational programs or participation in them as a rapporteur, member of the scientific group or trainer, writing and research work, initiatives in relation to the trainer implementation of educational programs and implementation of innovations, education-related administrative or guidance experience, training sessions, participation in councils, committees or working groups, social and trade union action, participation in governing scientific and educational organizations or in bodies of popular participation, official distinctions and excellence (Law 3848/2010). The word 'excellence' existed at 3848/2010, in 4327/2015 completely cut off). In order to qualify the interview, the Selection Board could also take into account a Candidate's Memorandum, which included a self-assessment report and scheduling of the planning work if selected. In order to evaluate the information in the memorandum, the applicant could submit relevant information in an annex.

The criterion of Personality \& General Character Formation rated up to 20 points maximum with the Law 3467/2006 on the basis of a curriculum vitae of the candidate accompanied by the necessary evidence and the details of his/her official file, and a personal interview of the candidate on pedagogical or organizational and administration issues of education. During the interview in 2006, it was assessed the ability of candidates to take initiatives, solve problems (administrative, teaching, organizational, operational, etc.), to create the appropriate pedagogical environment and to inspire teachers in the performance of their duties. Especially for the selection of teachers in positions of directors of musical or artistic schools, the personal interview of the candidate takes into account the special studies or the recognized artistic work and action.

During the interview, the candidate Director of the Model Experimental Lyceum in the 2013

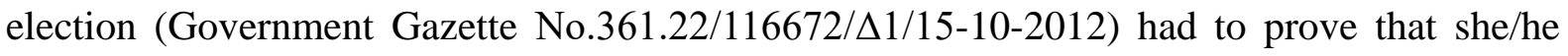
had the required qualifications to manage the school unit from the point of view of knowledge of the role and work of the school head as defined by the law and envisioned by the candidate, having the human resources management capabilities and leadership skills.

Only in 2015, the interview replaced by secret voting of the school teachers, which did not provide objection procedure, and was declared unconstitutional by the Council of State by decision No 711/2016. Through secret voting, personalities that had emerged in the everyday life of school life were valued, such as ethics, honesty, and sense of justice, democratic 
behavior, professional development and consistency (Law 4327/2015). Before voting, the Teachers' Association of the school had to take into account the evidence that the candidates had submitted and the information mentioned in his/her curriculum vitae. The number of points the candidate received in the secret ballot was calculated as follows: the percentage of votes that the candidate could received on the total number of valid votes was equal to the percentage of 12 points that the candidate could receive at most. A candidate who does not hold at least $20 \%$ of the valid votes in the secret ballot did not participate in the further selection process. In order the vote to be valid, an increased participation of at least $65 \%$ of the members of the school Teachers' Association was required.

Transformational leadership empowers teachers and raises their motivation towards their profession. An individual's value system is defined as an enduring organization of beliefs and rules that assist an individual in selecting alternatives, resolving conflicts and making decisions. Research studying the links between values and behavior has found that values influence behaviors. People differ from each other in the importance they attribute to different values. This different attribution is a person's hierarchy of values, reflecting on personality and guiding his perceptions, evaluations and choices of behavior. (Jamal, 2014). The existence of common values, such as cooperation, trust, open communication, etc., affects the behavior of the members of an organization, and knowing what they are trying to do to transform values into behavioral norms. These values define the character of the organization, give it an identity, and in some way a purpose of existence (Kiousi, 2008).

In candidates' competencies include, but are not limited to perceptual ability, communication and cooperative ability, ability to develop initiatives and solve problems in particular teaching, administrative, organizational and functional issues, as well as the ability to create an appropriate pedagogical environment for teachers to be inspired in the performance of their duties (Laws 3848/2010, 4327/2015). The ideal candidate in Rocketship schools should have, among the others, combination of the following abilities, skills to eliminate boundaries that impede workflow and information between schools, strong communication skills to translate business strategies and alignment of practices with company mission across the region, ability to think strategically and manage with whole function in mind (Rocketship, 2017). The research into the $\mathrm{PhD}$ thesis of (Nathanail, 2014) suggests that although collaboration between executives is considered to be one of the key factors in the qualitative upgrading of education, the Greek state has not yet made the necessary efforts to achieve this type of cooperation, given that cooperation is described in a small legislative context. Training in decision-making and problem-solving turns the career education into a field of learning and application of a broader set of transversal skills. At school, teaching of career management skills can be delivered either as cross-cutting subject, as separate subject or both. A cross-cutting approach integrating careers education into all key subjects offers advantages in terms of an integral, holistic perspective, teaching career management skills as a separate subject may, however, be easier to organize in terms of teachers' training or cooperation with external career guidance services (Kraatz, 2017).

\section{Epilogue}




\section{MInstitute ${ }^{\text {Mink }}$}

International Journal of Human Resource Studies

ISSN 2162-3058

2018, Vol. 8, No. 3

Concluding, the profile of the modern School Director of Secondary Education basically concerns his/her scientific and pedagogical formation and training, which is built through many qualifications, which are related to experience, educational work and personality. School heads are today faced with many varied tasks, including not only organizing teaching and learning but also managing financial and human resources. Selecting the right candidate for headship is crucial and so many different criteria must be considered when appointing. In all European countries, regulations set out the official requirements expected of those wishing to become school heads (EACEA/Eurydice, 2013). In Greece, the required qualifications, the characteristics and the points of rating, the interview etc. were matched by a separate set of criteria and with different weighting in the different selection periods, serving different political considerations, especially when political parts were changing in government. The formation and training of the modern and future school principal is a continuous apprenticeship process throughout his or her life, in the educational institutions as student, and as practitioner teacher or executive (Mavrogiorgos, 1993). For this, it is extremely difficult, through a massive selection procedure all over the Greece, each candidate, as a distinct personality, to be assessed with the best way and pictured her/his ideal professional profile for the modern school Director who will meet the challenges of the 21 st century schools.

\section{References}

Abu, H. J. (2014) Leadership Styles and Value Systems of School Principals, American Journal of Educational Research, 2014, 2(12), 1267-1276, Available online at http://pubs.sciepub.com/education/2/12/22, Science and Education Publishing, DOI:10.12691/education-2-12-22

Bell, J. (1997). Doing Your Research Project: A Guide For First-Time Researchers. New York: Open University Press.

Biniari, L. (2016) School Portrait as a School Unit Self-Assessment Tool, Greek Journal of Educational Evaluation, Edition of the Greek Society of Educational Evaluation, 1(1) \& 1(2), Special issue 1st Conference of the GSEE proceedings: "School Evaluation and Teachers Appraisal: Current Trends, Dilemmas and Perspectives", Athens, available at 22-02-2018 on http://www.eletea.gr/wp-content/uploads/2018/02/PRAKTIKA_TELIKO.pdf

Bird, M., Hammersley, M., Gomm, R., \& Woods, P. (1999). Educational Research in Action/ Fragkou E: Translate in Greek. Educational Research in Practice-Study Manual. Patras

CEC. (2007) Commission Staff Working Document Schools for the 21st Century, Commission of the European Communities, Brussels, 11.07.2007, SEC(2007) 1009

CEDEFOP. (2009). About us http://www.cedefop.europa.eu/about/default.asp

Cohen, L., \& Manion, L. (1994). Research Methods in Education (4th ed), London: Routledge

EACEA/Eurydice. (2013) European Commission/EACEA/Eurydice, 2013. Key Data on Teachers and School Leaders in Europe. 2013 Edition. Eurydice Report. Luxembourg: 
Publications Office of the European Union, ISBN 978-92-9201-412-4, doi:10.2797/91785, available on http://eacea.ec.europa.eu/education/eurydice

ECC. (2010) Joint progress report of the Council and the Commission on the implementation of the Education and Training 2010 work program, Note from the Education Committee to the Permanent Representatives Committee, Brussels, 18 January 2010, 5394/10, EDUC 11, SOC 21

ECVET. (2009) The European Credit System for Vocational Education and Training ECVET Get to know ECVET better Questions and Answers, EUROPEAN COMMISION Education and Culture Lifelong learning: Policies and Programme Professional training; Leonardo da Vinci

EP. (2006) Recommendation of the European Parliament and of the Council of 18 December 2006 on key competences for lifelong learning (2006/962 / EC) L 394/10 EN Official Journal of the European Union 30.12.2006

EU. (2006) Recommendation of the European Parliament and of the Council of 18 December 2006 on key competences for lifelong learning (2006/962 / EC), L394 / 10, 30.12.2006, available on $12 / 4 / 2017$ at http://eur-lex.europa.eu/legal-content/EL/TXT/PDF/?uri=CELEX:32006H0962\&from=EL

Hardman, B. K. (2011) Teacher's Perception of their Principal's Leadership Style and the Effects on Student Achievement in Improving and non-improving schools, University of South Florida, USA, available at 4-3-2018 on http://scholarcommons.usf.edu/etd/3726/

JEU. (2010) Notices from European Union institutions, bodies, offices and agencies council, 2010 joint progress report of the Council and the Commission on the implementation of the 'Education and Training 2010 work programme, (2010/C 117/01) Official Journal of the European Union 6.5.2010

Iosifidis, T. (2003). Analysis of Qualitative data in Social Sciences. Athens: Kritiki Publications

Kashyap, D. (2017) Top 7 Major Roles of a Headmaster, available 3-3-2018 on http://www.yourarticlelibrary.com/schools/headmaster-schools/top-7-major-roles-of-a-headm aster/63736/

Kassotakis, M. (Editor) (2016) Modern international trends in the evaluation of schools and teachers and the case of Greece, Greek Journal of Educational Evaluation, Edition of the Greek Society of Educational Evaluation, Volume 1, No 1(2016), No 2(2017), Special issue 1st Conference of the GSEE proceedings: "School Evaluation and Teachers Appraisal: Current Trends, Dilemmas and Perspectives", Athens, available at 22-02-2018 on http://www.eletea.gr/wp-content/uploads/2018/02/PRAKTIKA_TELIKO.pdf

Kiousi, S. (2008) Relationship of School Culture, Values and School Enhancement, Proceedings of the 2nd Panhellenic Conference titled "New Educational Material Assessment of Alumni and Secondary Education, Arta, March 2008 
Kordis, N. (2015) Demographics of Educational Directors \& School Leaders, Elected at KYSDE, available

26-02-2018 a

http://www.esos.gr/sites/default/files/articles-legacy/dimografika_stoiheia_diethynton_ekpaid eysis_kai_sholikon_monadon-1.pdf

Kraatz, S. (2017) Skills Development and Employment: The role of career management skills Author: (Seconded National Expert), Policy Department A: Economy and Scientific Policy, European Parliament, PE 607.359, available at 25-02-2018 on http://www.europarl.europa.eu/RegData/etudes/BRIE/2017/607359/IPOL_BRI(2017)607359 _EN.pdf

LEC. (2000) Lisbon European Council Presidency Conclusions, Lisbon European Council 23 and 24 March 2000, available 040216 on http://www.europarl.europa.eu/summits/lis1_en.htm Mavrogiorgos, G. (1993) At last Training in Regional Educational Centers (RTCs), Modern Education, 72, 11-13.

MPE. (2010). The contribution of investigative training needs in teacher education: Comparative Results, "Major Program of Teacher Training", available on 10/8/13 at http://www.epimorfosi.edu.gr/images/stories/e-books/ap_anagk/pdf/8_sysxetisi.pdf

Nathanail, P. (2014) The collaboration between the educational staff: theoretical analysis and empirical investigation, Aristotle University of Thessaloniki, Philosophical School, Department of Philosophy and Pedagogy, Department of Pedagogic, Doctoral Thesis, Thessaloniki

NSSD. (2010) The New School: First the Student, The Action Plan available at 4-4-2018 on http://pi-schools.gr

Rocketship. (2017) Rocketship Education, available at 3-3-2018 on www.rsed.org

SEC. (2007) Improving the Quality of Teacher Education, Communication from the Commission to the Council and the European Parliament, \{SEC(2007) 931, SEC(2007)933 Commission of the European Communities, Brussels, 3.8.2007, COM(2007) 392 final

Terzidis, \& Tzortzakis. (2004) Human Resource Management, Personnel Management, Rosili Publishing House, Athens ISBN9607745116

UNESCO. (2006) The New Roles of Secondary School Head-teachers, UNESCO Interagency Group on Secondary Education, Section for General Secondary Education, available at 3-3-2018 on http://unesdoc.unesco.org/images/0014/001490/149057e.pdf

\section{Copyright Disclaimer}

Copyright for this article is retained by the author(s), with first publication rights granted to the journal.

This is an open-access article distributed under the terms and conditions of the Creative Commons Attribution license (http://creativecommons.org/licenses/by/4.0/). 